\title{
VERSITA
}

Ekológia (Bratislava)

Vol. 32, No. 4, p. 376-382, 2013

doi:10.2478/eko-2013-0035

\section{DOUGLAS-FIR PROVENANCE PHENOLOGY OBSERVATIONS}

\author{
VERA LAVADINOVIĆ ${ }^{1}$, VASILIJE ISAJEV ${ }^{2}$, LJUBINKO RAKONJAC ${ }^{1}$, \\ VLADAN POPOVIĆ ${ }^{1}$, ALEKSANDAR LUČIĆ ${ }^{1}$ \\ ${ }^{1}$ Institute of Forestry, Kneza Višeslava 3, Belgrade, Serbia; e-mail: veralava@eunet.rs \\ ${ }^{2}$ Faculty of Forestry, Kneza Višeslava 1, Belgrade, Serbia
}

\begin{abstract}
Lavadinović V., Isajev V., Rakonjac L., Popović V., Lučić A.: Douglas-fir provenance phenology observations. Ekológia (Bratislava), Vol. 32, No. 4, p. 376-382, 2013.

Introduction of species involves adaptation, productivity and success in new types of environmental conditions. The introduction also includes confirmation to bring in only species which are superior on their natural habitat. In Canada and western North America, Douglas fir (Pseudotsuga menziesii/Mirb./Franco) is one of the most ecologically and economically value trees. In Europe, New Zealand, Australia and Chile, Douglas fir is important as an exotic fast-growing timber species. Douglas fir has one of the widest natural ranges of any tree species, extending from the Pacific Coast to the eastern slope of the Rocky Mountains and from $19^{\circ} \mathrm{N}$ in Mexico to $55^{\circ} \mathrm{N}$ in western Canada. In Serbia, from the original seeds introduced from British Columbia and Canada, the experimental Douglas-fir provenance is established in a few locations. One of the main dangers for the Douglas fir is its sensitivity to the occurrence of late frost in spring and early occurrence of frost in the autumn. The aim of the paper is to test the effect of environment on the expression of Douglas-fir seed transfer. Bud burst phenology is closely related to genecology of introduced species. Douglas fir is susceptible to cold climate and most of its genetic structure and ability depends on its ecological adaptability.

In order to avoid errors introduction of Douglas-fir provenances that are sensitive to the occurrence of extreme temperature, applied are researching for buds phenological changes Douglas fir, as an introduced species, has to be tested at the provenance level before its introduction to the new sites in Serbia.
\end{abstract}

Key words: Douglas-fir, phenology, ecological adaptation, provenance, Serbia.

\section{Introduction}

The phenology of bud burst is fundamental to tree survival and growth in temperate and boreal regions of the world (Sakai, Larcher, 1987; Bailey, Harrington, 2006). Early expansion of vegetative tissue is advantageous for producing biomass and maintaining site dominance; however, early tissue expansion also increases the risk of frost damage from late-spring freezing temperatures (Heide, 2003), and spring frosts are two to three times more likely than fall frosts to damage Douglas fir in the Pacific Northwest (Timmis et al., 1994). Plants have evolved mechanisms to use photoperiod and temperature cues to balance the benefits from 
early bud burst with the probability of significant damage from spring frost (Sakai, Larcher, 1987; Hannerz, 1999). Changes in microclimate around plants or prevailing landscape climate (IPCC, 2001) will alter that balance within and among species (Murray et al., 1989; Hänninen, 1995; Guak et al., 1998).

Institute of Forestry has set up several experiment plots in Serbia of different provenances of Douglas fir from the original seed from the part of species natural area. Ever since then, the Douglas-fir has been the subject of permanent research in Serbia.

During the years of research, the following have been studied: percentage survival of young plants, content of essential oils in the needles, height increment, comparison of diameter and height, anatomical analysis of wood and needles, physiological research and phenological bud-opening observations (Teševič et al., 2009; Lavadinović et al., 2010, 2011a,b). Douglas fir being the most promising introduced species in Europe, a decision has been made to set up the experimental test of Douglas fir in the environmental conditions of Serbia. Douglas fir (Pseudotsuga menziesii, Mirb/Franco) is also known as Douglas-fir, yellow or red spruce, Oregon pine, Black fir, British Columbia Douglas-fir, British Columbia pine, Canadian Douglas-fir, coast Douglas-fir, Colorado Douglas-fir, Colorado pino real, Columbian pine, gray Douglas, green Douglas, Douglas pine, Douglas spruce, Montana fir, Oregon Douglas-fir, Oregon fir, Red pine, Rocky Mountain Douglas-fir, Oregon spruce, Pacific Coast, Douglasia azzurra, Douglasia glauca, Golden rod fir, etc. Successful potential growth and wood quality and wide distribution throughout the western United States and Canada made the species as the most introduced in the world forestry.

Commercially, the tree is one of the world's most important and valuable timber trees and historically it was used by Westerners for telephone poles and railway ties among many other uses. This species grows rapidly. Douglas fir is the largest and tallest member of the Pine family. Living trees have been documented to be up to $485 \mathrm{~cm}$ in diameter, up to 99.4 $\mathrm{m}$ tall and with volumes up to $349 \mathrm{~m}^{3}$. Douglas fir is equally interesting for timber industry, forestry, landscape architecture, medical and cosmetic industries and the most popular is as a commercial production for Christmas tree. Hence being productive, commercially useful and widely popular and marketable, the Douglas fir is considered to be one of the most valuable conifers. Because of all these positive attributes, Douglas fir is a permanent subject of many researches and studies. The entire range includes central California, western Oregon and Washington, parts of the Rockies and extends north to Alaska. It grows under a wide variety of environments from extremely dry, low elevation sites to moist sites.

Such a wide natural range of the species, to selecting the right provenance for the new environmental conditions during the process of introduction. Late spring frosts and early fall frosts can damage plants provenance, which cannot adapt well, and are closely related to the adaptation, survival, tree height growth and productivity. The aim of this study is to continue the follow-up of the process of opening buds of Douglas-fir provenance originating from Canada in the experimental plots in Serbia.

\section{Material and methods}

'Phainestai', the ancient Greek word meaning to show or to appear, is found in many modern language words reflecting the original. The task of plant phenology is to observe and record the periodically recurring growth stages and 
to study the regularities and dependency of the yearly cycles of development on environmental conditions (Defila, Clot, 2001). Plant development and thus phenological phases show great inter-annual variability and also large spatial differences. Individual (genes and age) and environmental factors (weather and climate conditions in the micro- and macro-scale, soil conditions, water supply, diseases, competition, etc.) influence plants (Koch et al., 1992).

The experimental plots were established from the plants produced in the Forestry Institute nursery. The starting material was the original Douglas-fir seeds of 14 provenances from British Columbia in Canada. Table 1 shows the geographical characteristics of tested provenances. Phenological observations of bud break were performed twice a week. To be able to apply the statistical data processing, the dates were calculated in days from the beginning of the calendar year. The analysis of data was based on the methods of analysis of variance, regression and correlation.

T a b l e 1. Geographical co-ordinates of the tested Douglas-fir provenances and phenological data.

\begin{tabular}{|c|c|c|c|c|c|c|c|c|}
\hline \multirow[t]{2}{*}{ Provenance } & \multirow[t]{2}{*}{ Location } & \multirow{2}{*}{$\begin{array}{c}\text { Latitude } \\
\text { (0) }\end{array}$} & \multirow{2}{*}{$\begin{array}{c}\text { Longitude } \\
\text { (0) }\end{array}$} & \multirow{2}{*}{$\begin{array}{l}\text { Altitude } \\
\text { (m) }\end{array}$} & \multicolumn{4}{|c|}{ Day of bud break/year } \\
\hline & & & & & 2002 & 2003 & 2004 & 2005 \\
\hline 1 & Cranbrook & 49.42 & 115.33 & 1050 & 90.2 & 119.9 & 120.1 & 120.3 \\
\hline 2 & Inonoaklin & 49.83 & 118.17 & 671 & 70.5 & 110.9 & 106.1 & 111.8 \\
\hline 3 & Mann Creek & 51.58 & 120.17 & 600 & 76.2 & 112 & 110.5 & 112.6 \\
\hline 4 & Gavia Lake TFL 14 & 50.93 & 116.58 & 1070 & 88 & 121.2 & 117.2 & 121.5 \\
\hline 5 & Nine Bay TFL 14 & 50.97 & 116.53 & 975 & 83.4 & 113.2 & 109.1 & 114.1 \\
\hline 6 & Trout Cr Creek & 49.67 & 119.87 & 884 & 80.9 & 113 & 111.4 & 114.9 \\
\hline 7 & Michell CR & 49.9 & 119.62 & 1035 & 87.1 & 120.1 & 119 & 120.6 \\
\hline 8 & Salmo & 49.25 & 117.5 & 793 & 73.8 & 112.3 & 107.2 & 113.2 \\
\hline 9 & Mara Lake & 50.8 & 119 & 488 & 71.2 & 110.2 & 108.2 & 111 \\
\hline 10 & Monte C Creek & 50.62 & 119.87 & 701 & 78.3 & 116 & 116.1 & 117.1 \\
\hline 11 & Sheep Creek & 49.17 & 117.25 & 1000 & 86.2 & 119.2 & 121.3 & 120 \\
\hline 12 & Cooke Creek & 50.63 & 118.82 & 900 & 82.7 & 116.6 & 113.3 & 116.9 \\
\hline 13 & Benton & 49.2 & 117.42 & 933 & 81.9 & 115.1 & 114 & 116.9 \\
\hline 14 & Sun Creek & 50.13 & 115.87 & 1000 & 86 & 119.3 & 119.2 & 119.5 \\
\hline
\end{tabular}

\section{Results}

Differences in phenological observations in the reference period did not have a drastic change in the data because the weather conditions were almost uniform. There were no temperature extremes in spring, such as for any of the previous years, where there was significant damage of the plants.

The main statistical parameters of the variables applied in the study are presented in Table 2. To be able to analyse the dependence of bud-break time of provenances on their geographical characteristics, the matrix of coefficients of simple linear correlation is presented in Table 3. The most significant for the research are the correlations of the variables whose coefficients of correlation are highlighted, i.e. the correlations of geographical characteristics and time of bud break. As can be seen from Table 3, the significant effect on the time of bud break is shown only by the provenance altitude. The coefficients of correlation between altitude and time of bud break, in all the three study years, not only show strong correlation between these two variables $\left(r_{2002}=0.92 ; r_{2003}=0.82, r_{2004}=0.69\right.$ and $\left.r_{2005}=0.84\right)$, but are also statistically significant at the level $\mathrm{p}=0.001$ for the research in 2002, 2003 and 2005, and at the level $\mathrm{p}=0.01$ in 2004, which is a high statistical significance. 
$\mathrm{T}$ a b l e 2. The main statistical parameters of Douglas-fir provenances .

\begin{tabular}{|l|c|c|c|c|c|c|}
\hline Variable & Mean & Minimum & Maximum & Range & $\begin{array}{c}\text { Standard } \\
\text { deviation }\end{array}$ & $\begin{array}{c}\text { Coefficient } \\
\text { deviation }\end{array}$ \\
\hline Geographical latitude & 50.2 & 49.2 & 51.6 & 2.4 & 0.8 & 1.5 \\
\hline Geographical longitude & 118.0 & 115.3 & 120.2 & 4.8 & 1.6 & 1.4 \\
\hline Altitude & 864.3 & 488.0 & 1070.0 & 582.0 & 184.4 & 21.3 \\
\hline 2002 Bud-break day & 81 & 71 & 90 & 20 & 6 & 7.8 \\
\hline 2003 Bud-break day & 116 & 110 & 121 & 11 & 4 & 3.3 \\
\hline 2004 Bud-break day & 114 & 106 & 121 & 15 & 5 & 4.5 \\
\hline 2005 Bud-break day & 116.5 & 111 & 121.5 & 10.5 & 3.6 & 3.1 \\
\hline
\end{tabular}

T a b l e 3. Matrix of coefficients of simple linear correlation.

\begin{tabular}{|c|c|c|c|c|c|c|c|}
\hline \multirow[t]{2}{*}{ Variable } & \multirow[t]{2}{*}{ Latitude } & \multirow[t]{2}{*}{ Longitude } & \multirow[t]{2}{*}{ Altitude } & \multicolumn{4}{|c|}{ Day of bud break/Year } \\
\hline & & & & 2002 & 2003 & 2004 & 2005 \\
\hline Geographical latitude & 1.00 & 0.32 & -0.37 & -0.17 & -0.19 & -0.25 & -0.26 \\
\hline Geographical longitude & 0.32 & 1.00 & $-0.60^{*}$ & -0.50 & -0.44 & -0.33 & -0.60 \\
\hline Altitude & -0.37 & -0.60 * & 1.00 & $0.92^{\star * *}$ & $0.82^{\star \star \star}$ & $0.69^{\star *}$ & $0.84^{\star * *}$ \\
\hline 2002 Bud-break day & -0.17 & -0.50 & $0.92^{* * *}$ & 1.00 & $0.90^{* * *}$ & $0.85^{\star * *}$ & $0.91^{\star * *}$ \\
\hline 2003 Bud-break day & -0.19 & -0.44 & $0.82^{\star * \star}$ & $0.90^{\star * *}$ & 1.00 & $0.93^{\star * *}$ & $0.99^{* * *}$ \\
\hline 2004 Bud-break day & -0.25 & -0.33 & $0.69^{\star *}$ & $0.85^{\star * *}$ & $0.93^{\star * *}$ & 1.00 & $0.94^{* * *}$ \\
\hline 2005 Bud-break day & -0.26 & -0.60 & $0.84^{* * *}$ & $0.91^{\star * *}$ & $0.99^{* * *}$ & $0.94^{\star \star *}$ & 1.00 \\
\hline
\end{tabular}

* $\quad$ - Coefficient of correlation statistically significant $\mathrm{p}=0.05$

$\star * \quad$ - Coefficient of correlation statistically significant $p=0.01$

$* * *$ - Coefficient of correlation statistically significant $\mathrm{p}=0.001$

In all the four study years, the provenances from higher altitudes have later times of bud break. Time of bud break shows weak correlation with the provenance latitude and longitude. Similar research carried out with Douglas-fir provenances originating from the more southern parts - the United States of America - shows different results (Lavadinović et, al., 2004).In this respect, we developed the models of correlation of bud-break time and the provenance altitude in three study years:

2002 Bud-break day $=53.989+0.03145 *$ Altitude

$\mathrm{R}=0.92$

$$
\mathrm{R} 2=0.83
$$

$\mathrm{F}(1.12)=63.027 \quad \mathrm{p}<0.00000 \quad$ St. error of estimate: 2.6

2003 Bud-break day $=101.06+0.01687 *$ Altitude

$\mathrm{R}=0.82$

$$
\mathrm{R} 2=0.65
$$

$\mathrm{F}(1.12)=25.160 \quad \mathrm{p}<0.00030 \quad$ St. error of estimate: 2.2

2004 Bud-break day $=97.145+0.01923 *$ Altitude

$\mathrm{R}=0.69$

$$
\mathrm{R} 2=0.43
$$

$\mathrm{F}(1.12)=10.968 \quad \mathrm{p}<0.00620 \quad$ St. error of estimate: 3.9 
2005 Listanje dan $=102.364+0.01630$ * Altitude

$\mathrm{R}=0.84 \quad \mathrm{R}^{2}=0.69$

$\mathrm{F}(1,12)=29.75 \quad \mathrm{p}<0.0001 \quad$ St. error of estimate: 2.0

In equations (1), (2), (3) and (4), the regression coefficients and regression in general are statistically significant. In each of the following years the study results were inferior. This could possibly be explained by the gradual adaptation of individuals to local climate effects, i.e. by gradual decrease of the effect of the provenance altitude. Still, this thesis should be confirmed only by further multi-annual research.

The interdependence of the time of bud break in three different study years, i.e. their correlation coefficients which also all show a very high correlation and high significance, confirm the thesis on the different time of bud break by different provenances: although there are differences in time of bud break of individual provenances in three different years, which is the consequence of different meteorological conditions in the three study years, their strong correlation actually shows that some provenances have earlier or later bud-break times irrespective of the year (meteorological conditions).

The differences in average time of bud break in three study years are shown by the results of the analysis of variance presented in Table 4 . The results of the test of least significant differences (LSD) are presented in Table 5.

T a b le 4. Analysis of variance of the time of Douglas-fir bud break.

\begin{tabular}{|l|c|c|c|c|c|}
\hline Source & Sum of squares & Df & Mean square & F-Ratio & P-Value \\
\hline Between groups & 12274.8 & 3 & 4091.62 & 175.36 & 0.0000 \\
\hline Within groups & 1213.29 & 52 & 23.3325 & & \\
\hline Total (Corr.) & 13488.1 & 55 & & & \\
\hline
\end{tabular}

$\mathrm{T}$ a b le 5. Results of the test of least significant differences.

\begin{tabular}{|l|c|c|c|}
\hline & Count & Mean & Homogeneous groups \\
\hline 2002 & 14 & 81.1714 & $\mathrm{X}$ \\
\hline 2004 & 14 & 113.764 & $\mathrm{X}$ \\
\hline 2003 & 14 & 115.643 & $\mathrm{X}$ \\
\hline Contrast & 14 & 116.457 & $\mathrm{X}$ \\
\hline $2002-2003$ & Difference & $+/$-Limits & \\
\hline $2002-2004$ & ${ }^{*}-34.4714$ & 3.66356 & \\
\hline $2002-2005$ & ${ }^{*}-32.5929$ & 3.66356 & \\
\hline $2003-2004$ & ${ }^{*}-35.2857$ & 3.66356 & \\
\hline $2003-2005$ & 1.87857 & 3.66356 & \\
\hline $2004-2005$ & -0.814286 & 3.66356 & \\
\cline { 1 - 3 } & -2.69286 & 3.66356 & \\
\end{tabular}

* Statistically significant differences 
Table 4 shows the statistically significant differences between average times of bud break in three study years. The test of least significant differences (Table 5) shows that 2003, 2004 and 2005. represent the homogeneous groups, i.e. that in these two years there was no difference in the mean values of bud-break time. In these two years, on the average, the bud-break times of all provenances was late than in 2003 . This could be explained by different meteorological conditions occurring in 2002, 2003, 2004 and 2005.

\section{Conclusion}

Seed transfer and provenance selection must be made on the basis of analysis and variations of all characteristics of introduced species. Phenology is an important integrative parameter to assess the impact of climate change on ecosystems.

The information on phenological characteristics is most important for the introduced species because, Douglas fir being a frost-tender species can often suffer from late spring frost damage. In this context, the phenological observations were started in the experimental plots in Serbia of different provenances of Douglas fir, and the following can be concluded based on the previous years' observations:

- The provenances which were ecologically better adapted were singled out, which confirmed the justification of provenance tests.

- The influence of the time of opening of buds, studied provenances showed elevation of origin, regardless of the weather conditions in the study years. With the increase in the altitude of origin, provenance buds begin to open late.

- The provenance latitude and longitude do not affect significantly the time of bud break.

- The average time of bud break of all provenances during the three study years shows a significant statistical difference. Years 2003, 2004 and 2005 are homogeneous in this respect, i.e. there are no statistically significant differences between them in average values of bud break. This is probably the consequence of similar meteorological conditions in 2003, 2004 and 2005, which differed from those in 2002. This should be confirmed by a more detailed research which should include also the analysis of climate characteristics during the study year.

- $\quad$ Phenological observation phase of the buds opening will continue in subsequent years.

\section{Acknowledgements}

This paper was realized as a part of the project 'Studying climate change and its influence on the environment: impacts, adaptation and mitigation' (43007) financed by the Ministry of Education and Science of the Republic of Serbia within the framework of integrated and interdisciplinary research for the period 2011-2014.

\section{References}

Bailey, J.D. \& Harrington C.A. (2006). Temperature regulation of bud-burst phenology within and among years in a young Douglas-fir (Pseudotsuga menziesii) plantation in western Washington, USA. Tree Physiol., 26, 421-430. DOI: $10.1093 /$ treephys/26.4.421.

Campbell, R.K. (1986). Mapped genetic variation of Douglas-fir to guide seed transfer in Southwest Oregon. Silvae Genet., 35(2-3), 85-95.

Defila, C. (1992). Pflanzenphänologischer Kalender ausgewählter Stationen in der Schweiz. Klimatologie der Schweiz, Hrg. Schweizerische Meteorologische Anstalt, Heft 30/L, 1-233. 
Defila, C. \& Clot B. (2001). Phytophenological trends in Switzerland. Int. J. Biometeorol., 45, 203-207. DOI: 10.1007/ s004840100101.

Guak, S., Olsyzk, D.M., Fuchigami, L.H. \& Tingey D.T. (1998). Effects of elevated CO2 and temperature on cold hardiness and spring bud burst and growth in Douglas-fir (Pseudotsuga menziesii). Tree Physiol., 18, 671-679. DOI: $10.1093 /$ treephys/18.10.671.

Hannerz, M. (1999). Evaluation of temperature models for predicting bud burst in Norway spruce. Can. J. For. Res., 29, 9-19. DOI:10.1139/x98-175.

Hänninen, H. (1995). Effects of climatic change on trees from cool and temperate regions: an ecophysiological approach to modelling of bud burst phenology. Can. J. Bot., 73, 183-199. doi:10.1139/b95-022

Heide, O.M. (2003). High autumn temperature delays spring bud burst in boreal trees, counterbalancing the effect of climatic warming. Tree Physiol., 23, 931-936. DOI: 10.1093/treephys/23.13.931.

Koch, E., Bruns, E., Chmielewski, F.-M., Defila, C., Lipa, W. \& Menzel A. (1992). Guidelines for plant phenological observations.

Lavadinović, V., Koprivica, M. \& Isajev V. (2004). Phenological characters of Douglas-fir provenances in Serbia. Silva Balcanica, 4(1), 89-94.

Lavadinović, V. Isajev, V. \& Miletić Z. (2010). Significance of genetic potential of Douglas-fir introduced provenances in Serbia for the ranking of their adaptation to climate changes. In IUFRO and EFI International scientific conference "Forest ecosystems and climate changes" (pp. 71-80). Belgrade, 9-10 $0^{\text {th }}$ March, Serbia

Lavadinović, V., Miletić, Z., Isajev, V. \& Krstć M. (2011a). Variability of nitrogen content in the needles of Douglasfir (Pseudotsuga Menziesii Mir / Franco) provenance. Genetika, 43(2), 407-417. DOI: 10.2298/GENSR1102407L

Lavadinović, V., Isajev, V. \& Popović V. (2011b). Uticaj staništa na širinu transfuzionog parenhima provenijencija duglazije u test kulturama u Srbiji. In Zbornik abstrakta IV Simpozijuma sekcije za oplemenjivanje organizama društva genetičara Srbije (p. 88). Kladovo 2-6.oktobra 2011.

Ministry of Environment, Lands and Parks British Columbia (1999). Douglas-fir ecosystems. Victoria: Conservation Data Centre.

Murray, M.B., Cannell, M.G.R. \& Smith R.I. (1989). Date of budburst of fifteen tree species in Britain following climatic warming. J. Appl. Ecol., 26, 693-700. http://www.jstor.org/stable/2404093

Sakai, A. \& Larcher W. (1987). Frost survival of plants: responses and adaptation to freezing stress. Berlin: SpringerVerlag.

Teševič, V. \& Lavadinović V. (2009). Analysis and antifungal activity essential oil of Douglas-fir (Pseudotsuga menziesii) from Serbia. Journal of the Serbian Chemical Society, 74(10), 1035-1040. DOI: 10.2298/JSC0910035T.

Timmis, R., Flewelling, J. \& Talbert C. (1994). Frost injury prediction model for Douglas-fir seedlings in the Pacific Northwest. Tree Physiol., 14, 855-869. DOI: 10.1093/treephys/14.7-8-9.855. 